\title{
Expression and Function of $\beta 1$ Integrins on Human Eosinophils
}

\author{
Maria-Cristina Seminario, Bruce S Bochner ${ }^{+}$
} Department of Medicine, Division of Clinical Immunology, Johns Hopkins Asthma and Allergy Center, The
Johns Hopkins University, Hopkins Bayview Circle, Baltimore, MD 21224-6801, USA

Eosinophils preferentially accumulate at sites of chronic allergic diseases such as bronchial asthma. The mechanisms by which selective eosinophil migration occurs are not fully understood. However, interactions of cell-surface adhesion molecules on the eosinophil with molecular counterligands on endothelial and epithelial cells, and on extracellular matrix proteins, are likely to be critical during the recruitment process. One possible mechanism for selective eosinophil recruitment involves the $\alpha 4 \beta 1$ (VLA-4) integrin which is not expressed on neutrophils. Correlations have been found between infiltration of eosinophils and endothelial expression of VCAM-1, the ligand for $V L A-4$, in the lungs of asthmatic individuals as well as in late phase reactions in the lungs, nose and skin. Epithelial and endothelial cells respond to the Th2-type cytokines IL-4 and IL-13 with selective de novo expression of VCAM-1, consistent with the possible role of VCAM-1/VLA-4 interactions in eosinophil influx during allergic inflammation. Both $\beta 1$ and $\beta 2$ integrins on eosinophils exist in a state of partial activation. For example, eosinophils can be maximally activated for adhesion to VCAM-1 or fibronectin after exposure to $\beta 1$ integrin-activating antibodies or divalent cations, conditions that do not necessarily affect the total cell surface expression of $\beta 1$ integrins. In contrast, cytokines like IL-5 prevent $\beta 1$ integrin activation while promoting $\beta 2$ integrin function. Furthermore, ligation of integrins can regulate the effector functions of the cell. For example, eosinophil adhesion via $\beta 1$ and/or $\beta 2$ integrins has been shown to alter a variety of functional responses including degranulation and apoptosis. Thus, integrins appear to be important in mediating eosinophil migration and activation in allergic inflammation. Strategies that interfere with these processes may prove to be useful for treatment of allergic diseases.

Key words: eosinophil - interleukin - $\beta 1$ integrins - allergic diseases

Eosinophil accumulation is a distinctive feature of allergic airways inflammation (Bochner et al. 1994). Evidence for a role of eosinophils in the airway inflammation in asthma comes from a variety of studies. The presence of increased numbers of these cells has been demonstrated in bronchial biopsies, bronchoalveolar lavage (BAL) fluid and

This work was supported by grant HL49545 from the National Institutes of Health and an Underrepresented Minority Investigator in Asthma and Allergy Award to Dr Seminario from the National Institutes of Health and the American Academy of Allergy, Asthma, and Immunology. Dr Bochner was also supported in part by a Developing Investigator Award from the Burroughs Wellcome Fund and a grant from the Office of Naval Research, awarded through the Asthma and Allergy Foundation of America.

${ }^{+}$Corresponding author. Fax: +1-410-550.2130. E-mail: bbochner@welchlink.welch.jhu.edu

Received 3 September 1997

Accepted 30 September 1997 peripheral blood of patients with asthma. Furthermore, these cells appear to be in an activated state or in the process of degranulation and the levels of their granule proteins have been extensively correlated with clinical symptoms of asthma.

Recent studies on the role of eosinophils have focused on the mechanisms by which these cells infiltrate the airways (Resnick \& Weller 1993, Bochner \& Schleimer 1994). Although the exact mechanisms by which selective eosinophil recruitment occurs remain incompletely defined, leukocyte recruitment is known to result from the interaction of cell-surface adhesion molecules (e.g., selectins, integrins, and immunoglobulin superfamily members) with molecular counterligands on vascular endothelial cells, extracellular matrix (ECM) proteins, epithelial cells and other tissue structures (Carlos \& Harlan 1994, Bochner \& Schleimer 1997). While other factors determine the phenotype of infiltrating cells, such as cytokines and chemokines (Springer 1995), this chapter will focus on the role of $\beta 1$ integrins in eosinophil trafficking and function. 


\section{EXPRESSION OF INTEGRINS ON EOSINOPHILS}

Integrins are plasma membrane receptors composed of $\alpha$ and $\beta$ heterodimeric transmembrane subunits generated from at least $16 \alpha$ and $8 \beta$ subunits to produce over 20 different receptors (Bochner \& Schleimer 1997). Both chains are required for normal receptor expression and for ligand binding. Members of the integrin family mediate cell-to-cell and cell-to-extracellular matrix interactions.

Table summarizes the expression of integrins on eosinophils. The predominant integrins on all leukocytes are in the $\beta 2$ (CD18) subfamily (Bochner \& Schleimer 1997). Granulocytes including eosinophils express the $\beta 2$ integrins LFA-1, Mac-1, p150,95 and $\alpha d \beta 2$ (Grayson et al. 1997). LFA-1 binds specifically to intercellular adhesion molecule-1 (ICAM-1), ICAM-2 and ICAM-3, Mac-1 binds to ICAM-1 and the $\mathrm{iC} 3 \mathrm{~b}$ product of activated complement, $\alpha \mathrm{d} \beta 2$ recognizes ICAM-3, while cellular ligands for $\mathrm{p} 150,95$ are as yet unknown. Because all granulocytes express $\beta 2$ integrins, there appears to be no immediate explanation for how they might contribute to selective eosinophil recruitment. However, there are conditions under which eosinophil $\beta 2$ integrins, especially Mac-1, may be selectively altered by stimuli such as cytokines [e.g., IL-5 (Walsh et al. 1990)] and chemokines (e.g., eotaxin) (Burke Gaffney \& Hellewell 1996).

When other integrins are examined, more obvious differences in expression among granulocytes are observed (Georas et al. 1993, Ebisawa et al. 1995). Unlike neutrophils, eosinophils express the $\alpha 4$ integrins VLA-4 $(\alpha 4 \beta 1)$ and $\alpha 4 \beta 7$ which mediate binding to VCAM-1, an immunoglobulin superfam-

TABLE

Expression of integrins on human eosinophils ${ }^{a}$

\begin{tabular}{lcc}
\hline Integrin & CD designation & Expression \\
\hline$\alpha 1 \beta 1$ & $49 \mathrm{a} / 29$ & No \\
$\alpha 2 \beta 1$ & $49 \mathrm{~b} / 29$ & No \\
$\alpha 3 \beta 1$ & $49 \mathrm{c} / 29$ & No \\
$\alpha 4 \beta 1$ & $49 \mathrm{~d} / 29$ & Yes \\
$\alpha 5 \beta 1$ & $49 \mathrm{e} / 29$ & No \\
$\alpha 6 \beta 1$ & $49 \mathrm{f} / 29$ & Yes \\
$\alpha \mathrm{L} \beta 2$ & $11 \mathrm{a} / 18$ & Yes \\
$\alpha \mathrm{M} \beta 2$ & $11 \mathrm{~b} / 18$ & Yes \\
$\alpha \mathrm{X} \beta 2$ & $11 \mathrm{c} / 18$ & Yes \\
$\alpha \mathrm{d} \beta 2$ & $\alpha \mathrm{d} / 18$ & Yes \\
$\beta 3$ & 61 & No \\
$\beta 4$ & 104 & No \\
$\beta 5$ & none & Unknown \\
$\beta 6$ & none & Unknown \\
$\alpha 4 \beta 7$ & $49 \mathrm{~d} / 103$ & Yes \\
\hline
\end{tabular}

$a$ : based on data from (Georas et al. 1993, Ebisawa et al. 1995, Grayson et al. 1997). ily member induced by cytokines on endothelium and epithelial cell lines (Atsuta et al. 1997, Bochner \& Schleimer 1997), and to an alternatively spliced domain in fibronectin, CS-1 (Anwar et al. 1994, Matsumoto et al. 1997). The $\alpha 4 \beta 7$ integrin binds to the mucosal addressin cell adhesion molecule-1 (MAdCAM-1) that has structural homology to ICAM-1 and VCAM-1 (Walsh et al. 1996, Briskin 1997). Eosinophils also express $\alpha 6 \beta 1$ (VLA-6), a ligand for the extracellular matrix protein laminin (Georas et al. 1993, Tourkin et al. 1993). Basophils resemble eosinophils in that they too express $\alpha 4 \beta 1$ and $\alpha 4 \beta 7$, but instead of $\alpha 6 \beta 1$, they express $\alpha 5 \beta 1$, another ligand for fibronectin (Saini et al. 1997).

\section{EOSINOPHIL-ENDOTHELIAL INTERACTIONS THROUGH $\beta 1$ INTEGRINS}

One mechanism of selective eosinophil recruitment involves the $\beta 1$ integrin $\alpha 4 \beta 1$ (VLA-4), which is expressed on human eosinophils but not on neutrophils. This may be important for allergic inflammatory responses since it is a receptor for VCAM1 , and correlations have been found between infiltration of eosinophils and expression of VCAM-1 in the lungs of patients with asthma as well as in late phase reactions in the lungs, nose or skin (Kyan-Aung et al. 1991, Bentley et al. 1993, Lee et al. 1994, Gosset et al. 1994, Ohkawara et al. 1995, Fukuda et al. 1996). Expression of VCAM-1 also correlated with eosinophil numbers in nasal polyp tissues (Jahnsen et al. 1995, Beck et al. 1996).

Resting endothelial cells do not express VCAM1. However, exposure of endothelial cells to IL-1, $\mathrm{TNF}$, or bacterial endotoxin induces expression of endothelial adhesion molecules, including ICAM1, E-selectin and VCAM-1. Specific antibodies to ICAM-1 and E-selectin have been shown to inhibit adherence of eosinophils to IL-1 stimulated endothelial monolayers by about 20-30\% (Bochner et al 1991). In contrast, VCAM-1 antibodies are extremely effective at inhibiting eosinophil but not neutrophil adherence (Bochner et al. 1991). Furthermore, anti-VLA-4 antibodies inhibit eosinophil, but not neutrophil, adhesion to IL-1 stimulated endothelium (Dobrina et al. 1991, Walsh et al. 1991). These results indicate that specific induction of VCAM-1 on endothelial cells could selectively promote eosinophil adherence.

Eosinophils are predominant at inflammatory sites where Th2-type cytokines, such as IL-4 and IL-13, are prevalent (Hamilos et al. 1996, Rankin et al. 1996). In vitro, both of these cytokines selectively lead to the induction of VCAM-1 expression without any significant effect on the expression of E-selectin or ICAM-1 on endothelial cells (Schleimer et al. 1992, Kaiser et al. 1993, Bochner et al. 1995). Furthermore, incubation of endothelial cells with 
IL-4 or IL-13 has no effect on neutrophil adhesion but induces eosinophil adhesion in a dose-dependent manner (Schleimer et al. 1992, Bochner et al. 1995). These cytokines can be synergistic and selective in their ability to induce VCAM-1 on endothelial cells. The combination of IL-4 with either IL1 or TNF results in at least 5-fold higher levels of VCAM-1 surface expression than either cytokine alone, with no induction of ICAM-1 or E-selectin (Iademarco et al. 1995, Ebisawa et al. 1997).

Further support for the potential importance of $\beta 1$ integrins and their ligands is provided by in vivo studies where the function of these adhesion molecules, or the cytokines that induce their expression, has been blocked. Efforts to antagonize VLA-4, VCAM-1, and IL-4 have all been shown to reduce eosinophil recruitment and allergic airways or cutaneous inflammation in a variety of animal models (Gonzalo et al. 1996, Richards et al. 1996, Lobb 1997, Fryer et al. 1997).

\section{EOSINOPHIL-EXTRACELLULAR MATRIX (ECM) IN- TERACTIONS THROUGH $\beta 1$ INTEGRINS}

After migration through the endothelium, eosinophils come into contact with the proteins of the basement membrane and ECM. The ECM is a complex web of large fibrillar proteins that underlies the endothelium and epithelium and surrounds connective tissue cells. Cellular interactions with ECM proteins can have profound consequences on leukocyte function (Hunt et al. 1997). Eosinophils interact with two ECM proteins, fibronectin and laminin, through two $\beta 1$ integrins, namely VLA-4 and VLA-6 ( $\alpha 6 \beta 1)$, respectively.

Fibronectin - Fibronectin is encoded by a single gene, but alternative splicing of the primary RNA transcript gives rise to polypeptide diversity that appears to be regulated in a cell type-specific fashion (Walsh \& Wardlaw 1997). The IIICS region of fibronectin contains a 25 amino acid site, named CS-1, that contains a sequence (LDV) recognized by VLA-4. Plasma fibronectin lacks the IIICS binding site in at least half of its subunits, whereas tissue fibronectin has it in both subunits. Despite expression of $\alpha 4$ integrins on eosinophils, whether they spontaneously attach to fibronectin remains controversial. Some studies have shown that resting eosinophils adhere to fibronectin in a VLA-4dependent manner and exhibit prolonged survival via autocrine production of cytokines such as GMCSF (Anwar et al. 1994, Neeley et al. 1994, Walsh et al. 1995). Other studies, however, have found little or no adhesion without prior activation with platelet-activating factor, $\mathrm{Mn}^{++}$or a $\beta 1$ integrin-activating antibody (Kuijpers et al. 1993, Kita et al. 1996, Matsumoto et al. 1997). A possible explanation for these discrepancies may arise from the fact that eosinophils express the $\beta 2$ integrin Mac-1, and engagement through this receptor to a different site on fibronectin, or to the blocking protein (typically albumin), may be occurring.

Eosinophils also express $\alpha 4 \beta 7$, another ligand for fibronectin (Erle et al. 1994, Walsh et al. 1996). Levels of $\alpha 4 \beta 7$ on eosinophils are comparable to those for $\alpha 4 \beta 1$. In addition to functioning as a fibronectin ligand, it can also be a ligand for MAdCAM-1 and VCAM-1 (Erle et al. 1994, Walsh et al. 1996). However, $\alpha 4 \beta 7$ on eosinophils appears to be relatively inactive, because activation with $\mathrm{Mn}^{++}$is required to demonstrate consistent adhesion (unpublished observations).

Laminin - Laminin consists of 3 distinct chains coded for by different but related genes. The mechanism by which laminin interacts with cells is complex (Walsh \& Wardlaw 1997). It is recognised by different integrin receptors including $\alpha 1 \beta 1$, $\alpha 2 \beta 1, \alpha 3 \beta 1, \alpha 6 \beta 1$ and $\alpha v \beta 3$, of which only $\alpha 6 \beta 1$ appears to be specific for laminin. Eosinophils can adhere to plate-bound laminin; this interaction requires divalent cations and is completely abolished by anti- $\alpha 6$ or anti- $\beta 1$ antibodies. Indeed, eosinophils were shown by flow cytometry and immunoprecipitation to express $\alpha 6 \beta 1$ (Georas et al. 1993). As has been shown for fibronectin, eosinophils cultured on laminin exhibit prolonged survival (Tourkin et al. 1993).

\section{EOSINOPHIL-EPITHELIAL INTERACTIONS THROUGH $\beta 1$ INTEGRINS}

Airway epithelium may also be an active participant in allergic inflammation. Epithelial cells are biologically active, express adhesion receptor proteins, and produce cytokines and chemokines (Polito \& Proud 1997). Until recently, only ICAM1, but not E-selectin or VCAM-1, had been identified in the respiratory epithelium in vitro and in in vivo biopsies from patients with asthma (Bloemen et al. 1993, Fukuda et al. 1996, Stark et al. 1996). However, in the BEAS-2B bronchial epithelial cell line, culture with TNF or IL-1 was found to induce VCAM-1 mRNA and cell surface expression (as well as ICAM-1 expression), while culture with IL-4 induced VCAM-1 but not ICAM-1 expression (Atsuta et al. 1997). Maximal VCAM-1 expression resulted from the combination of TNF and IL-4. Furthermore, TNF treatment increased adhesion of eosinophils to BEAS-2B monolayers and this adhesion was blocked with VCAM-1 antibodies. These findings suggest that cytokine activation can induce expression of VCAM-1 on airway epithelium which can functionally interact with eosinophils through VLA-4. 


\section{ALTERATIONS IN FUNCTION VERSUS EXPRESSION OF $\beta 1$ INTEGRINS ON EOSINOPHILS}

Levels of $\alpha 4 \beta 1$ and $\alpha 6 \beta 1$ on eosinophils are not altered after migration in vitro or in vivo or after cytokine activation, nor do levels differ among hypodense versus normodense eosinophils or cells from allergic versus nonallergic donors (Georas et al. 1992, 1993, Hansel \& Walker 1992, Kroegel et al. 1994). However, in addition to the amount of expression of cell surface adhesion molecules, the functional state of integrins can be regulated, leading to changes in the affinity for counterligand binding without changing the level of cell surface expression (Diamond \& Springer 1994). Recent studies have shown that the activation state of integrins can influence cell adhesion and function. The avidity of integrins, not just the total number of molecules expressed, influences cell adhesion and migration (Hunt et al. 1997). While a particular integrin may have more than one ligand, the avidity for each ligand may differ. It has recently been demonstrated that $\alpha 4 \beta 1$ integrins on eosinophils exist in a state of partial activation, and can be maximally activated for adhesion to ligands such as fibronectin and VCAM-1 after exposure to manganese or integrinactivating antibodies, conditions that do not affect the total cell surface expression of $\beta 1$ integrins (Werfel et al. 1996, Matsumoto et al. 1997). Maintenance of basal levels of $\beta 1$ integrin function on eosinophils appears to require tyrosine kinase activity, because reversible downregulation of VCAM1 adhesion is seen in cells exposed to genistein or tyrphostins (Nagata et al. 1995, Matsumoto et al. 1997).

\section{SIGNALING VIA $\beta 1$ INTEGRINS ON EOSINOPHILS}

Outside-in signaling - Adhesion molecules are not only involved in adhesive interactions but also in transducing signals from the extracellular to the intracellular compartments and regulating effector functions of the cell (Ginsberg et al. 1992, Clark \& Brugge 1995). For eosinophils, ligation of integrins has been shown to alter a variety of functional responses (Dri et al. 1991, Anwar et al. 1993, Tourkin et al. 1993, Neeley et al. 1994, Nagata et al. 1995, Kita et al. 1996). Signaling mechanisms via integrins are still poorly understood. The intracytoplasmic domains of integrins lack kinase or phosphatase activity of their own; they also lack sequence homology with known signaling proteins (Hemler et al. 1994). However, recent reports have shown that integrin engagement, either with ligand or with antibodies, is capable of transducing signals (Miyamoto et al. 1995) and induces the phosphorylation of the tyrosine kinase pp125 $5^{\mathrm{FAK}}$ (FAK) (Schaller \& Parsons 1994).
Outside-in signaling is initiated by the $\beta$ subunit cytoplasmic-domain dependent rearrangement of cytoskeletal components and actin into focal adhesion complexes (FAC), found at areas of cellECM interaction (Clark \& Brugge 1995). Formation of FAC's in adherent cells is thought to be associated with cell spreading. A predominant FAC's component, FAK, has been shown to physically interact with the cytoplasmic domain of $\beta$ integrins, which in turn is thought to recruit several signaling molecules to FAC's (Schaller \& Parsons 1994). It is not clear whether the cytoskeletal and signaling components found in FAC's associate with integrins in leukocytes. Besides FAK, $\beta 1$ integrin interacts directly or indirectly with cytoskeletal proteins (McArthur Lewis \& Schwartz 1995, Yamada \& Miyamoto 1995, Wahl et al. 1996).

In addition to FAK, integrin receptor occupancy leads to the activation of the Src family of tyrosine kinases (Shattil et al. 1994) and the Ras/MAP kinase pathway (Schaller \& Parsons 1994). Recently a novel serine/threonine kinase has been reported to associate with the $\beta 1$ integrin cytoplasmic domain (Hannigan et al. 1996). The $59 \mathrm{kD}$ protein, known as integrin-linked kinase (ILK), was found to phosphorylate a peptide representing the $\beta 1$ integrin cytoplasmic domain and to co-localize with $\beta 1$ in focal plaques.

Outside-in signaling is also regulated by the $\alpha$ subunit cytoplasmic tails. Those of $\alpha 2$ and $\alpha 5$ localize predominantly to FAC's and show increased spreading on ECM. In contrast, the expression of the $\alpha 4$ cytoplasmic tail correlates with chemo and haptotactic migration, suggesting that $\alpha 4$ is responsible for weaker integrin-cytoskeletal interactions (Kassner et al. 1995). This is a potential mechanism by which $\alpha 4 \beta 1$, highly expressed in eosinophils, could increase cell motility.

Inside-out signaling - The rapidity of insideout signaling insures that leukocytes can quickly modify their adhesiveness in response to stimuli. This is achieved by changes in integrin functional activity rather than integrin expression on the cell surface. The signaling pathways involved in inside-out signaling are still ill-defined (Hunt et al. 1997). Recent progress in this field has been mainly in $\mathrm{T}$ cells. Several activation stimuli have been shown to upregulate integrin function. Treatment of T cells with PMA or the $\mathrm{Ca}+2$ ionophore A23187 has been shown to upregulate integrin-mediated $\mathrm{T}$ - cell adhesion, indicating that both protein kinase $\mathrm{C}$ and $\mathrm{Ca}+2$ are involved in the intracellular signaling events (Shimizu et al. 1990), whereas treatment of Jurkat cells with the serine-threonine phosphatase inhibitor okadaic acid depresses fibronectin adhesion through $\beta 1$ integrins (Seminario et al. 
1997). Furthermore, cell-surface receptors, called integrin regulators, can induce an inside-out signal. These integrin regulators include the TCR complex, CD2, CD28, CD7 (Chan et al. 1991, Shimizu et al. 1992) and cell surface signaling proteins of the transmembrane-4 superfamily that include CD9, CD53, CD63, CD82 and CD81 (Mannion et al. 1996).

Receptors for chemokines have been shown to be a class of integrin regulators for leukocyte interactions with the endothelium (Springer 1990, del Pozo et al. 1995). Chemokine receptors belong to the seven membrane spanning family of $G$ protein coupled receptors (Schall \& Bacon 1994, Teran \& Davies 1996). Signaling through chemokine receptors is thought to be very rapid inducing integrin activity within minutes. For example, the chemokines RANTES, MCP-1, MIP- $1 \alpha$ and MIP$1 \beta$ have been shown to upregulate $\beta 1$ integrin mediated adhesion of T cells (Carr et al. 1996), monocytes (Weber et al. 1996) and eosinophils (Weber et al. 1996b) to counterreceptors and ECM ligands.

\section{CONCLUSIONS}

Eosinophils selectively migrate to sites of chronic allergic inflammation where they are thought to be one of the major contributors to the underlying pathology. An initial step in the recruitment of leukocytes is their adhesion to endothelium, followed by transendothelial migration and chemotaxis into tissue parenchyma. Several adhesion molecules have been implicated in eosinophil adherence, however, VLA-4, which is not present in neutrophils, provides a potential mechanism by which specific recruitment occurs. This chapter has reviewed the biology of $\beta 1$ integrins on eosinophils and their potential roles in preferential cellular trafficking. Although the exact mechanisms of tissue eosinophilia are yet to be fully defined, it is clear that $\beta 1$ integrin-mediated adhesion to tissue structures are important for cellular migration and is capable of altering cellular function. Further elucidation of this process should lead to a better understanding of mechanisms of allergic inflammation, and may ultimately lead to the design of better therapies for allergic diseases.

\section{REFERENCES}

Anwar ARE, Walsh GM, Cromwell O, Kay AB, Wardlaw AJ 1994. Adhesion to fibronectin primes eosinophils via alpha(4)/beta(1) (VLA-4). Immunology 82: 222.

Anwar ARF, Moqbel R, Walsh GM, Kay AB, Wardlaw AJ 1993. Adhesion to fibronectin prolongs eosinophil survival. J Exp Med 177: 839.

Atsuta J, Sterbinsky SA, Schweibert LA, Bochner BS, Schleimer RP 1997. Phenotyping and cytokine regulation of the human bronchial epithelial cell line BEAS-2B: demonstration of inducible expression of the adhesion molecules VCAM-1 and ICAM-1. Am J Respir Cell Mol Biol (in press)

Beck LA, Stellato C, Beall LD, Schall TJ, Leopold D, Bickel CA, Baroody F, Bochner BS, Schleimer RP 1996. Detection of the chemokine RANTES and endothelial adhesion molecules in nasal polyps. $J$ Allergy Clin Immunol 98: 766.

Bentley AM, Durham SR, Robinson DS, Menz G, Storz C, Cromwell O, Kay AB, Wardlaw AJ 1993. Expression of endothelial and leukocyte adhesion molecules intercellular adhesion molecule-1, E-selectin, and vascular cell adhesion molecule-1 in the bronchial mucosa in steady-state and allergen-induced asthma. J Allergy Clin Immunol 92: 857.

Bloemen PG, van den Tweel MC, Henricks PAJ, Engels F, Wagenaar SS, Rutten AAJJL, Nijkamp FP 1993. Expression and modulation of adhesion molecules on human bronchial epithelial cells. Am J Respir Cell Mol Biol 9: 586.

Bochner BS, Klunk DA, Sterbinsky SA, Coffman RL, Schleimer RP 1995. Interleukin-13 selectively induces vascular cell adhesion molecule-1 (VCAM-1) expression in human endothelial cells. J Immunol 154: 799.

Bochner BS, Luscinskas FW, Gimbrone MA Jr, Newman, W, Sterbinsky SA, Derse-Anthony C, Klunk D, Schleimer RP 1991. Adhesion of human basophils, eosinophils, and neutrophils to IL-1-activated human vascular endothelial cells: contributions of endothelial cell adhesion molecules. J Exp Med 173: 1553.

Bochner BS, Schleimer RP 1994. The role of adhesion molecules in human eosinophil and basophil recruitment. J Allergy Clin Immunol 94: 427.

Bochner BS, Schleimer RP 1997. Endothelial cells and cell adhesion. In AP Kaplan, Allergy. 2nd ed., WB Saunders, Orlando (in press).

Bochner BS, Undem BJ, Lichtenstein LM 1994. Immunological aspects of allergic asthma. Annu Rev Immunol 12: 295.

Briskin M 1997. Pathways of cell recruitment to mucosal surfaces, p. 105. In BS Bochner, Adhesion molecules in allergic diseases, Marcel Dekker, New York.

Burke Gaffney A, Hellewell PG 1996. Eotaxin stimulates eosinophil adhesion to human lung microvascular endothelial cells. Biochem Biophys Res Commun 227: 35 .

Carlos TM, Harlan JM 1994. Leukocyte-endothelial adhesion molecules. Blood 84: 2068.

Carr MW, Alon R, Springer TA 1996. The C-C chemokine MCP-1 differentially modulates the avidity of beta 1 and beta 2 integrins on $\mathrm{T}$ lymphocytes. Immunity 4: 179 .

Chan B, Wong J, Rao A, Hemler M 1991. T-cell receptor-dependent, antigen-specific stimulation of a murine $\mathrm{T}$ cell clone induces a transient, VLA proteinmediated binding to extracellular matrix. J Immunol 147: 398.

Clark EA, Brugge JS 1995. Integrins and signal transduction pathways: the road taken. Science 268: 233.

del Pozo MA, Sanchez-Mateos P, Nieto M, Sanchez- 
Madrid F 1995. Chemokines regulate cellular polarization and adhesion receptor redistribution during lymphocyte interaction with endothelium and extracellular matrix. Involvement of cAMP signaling pathway. J Cell Biol 131: 495.

Diamond MS, Springer TA 1994. The dynamic regulation of integrin adhesiveness. Curr Biol 4: 506.

Dobrina A, Menegazzi R, Carlos TM, Nardon E, Cramer R, Zacchi T, Harlan JM, Patriarca P 1991. Mechanisms of eosinophil adherence to cultured vascular endothelial cells: eosinophils bind to the cytokineinduced endothelial ligand vascular cell adhesion molecule- 1 via the very late activation antigen- 4 integrin receptor. J Clin Invest 88: 20.

Dri P, Cramer R, Spessotto P, Romano M, Patriarca P 1991. Eosinophil activation on biological surfaces. Production of $\mathrm{O}_{2}^{-}$in response to soluble stimuli is differentially modulated by extracellular matrix components and endothelial cells. J Immunol 147: 613.

Ebisawa M, Bochner BS, Schleimer RP 1997. Eosinophil-endothelial interactions and transendothelial migration, p. 173. In BS Bochne, Adhesion molecules in allergic diseases, Marcel Dekker, Inc., New York.

Ebisawa M, Schleimer RP, Bickel C, Bochner BS 1995. Phenotyping of purified human peripheral blood eosinophils using the blind panel mAb, p. 1036. In S Schlossman, L Boumsell, W Gilks, J Harlan, T Kishimoto, C Morimoto, J Ritz, S Shaw, R Silverstein, T. Springer, T Tedder, R Todd (eds), Leukocyte Typing V: White Cell Differentiation Antigens, Oxford University Press, New York.

Erle DJ, Briskin MJ, Butcher EC, Garcia Pardo A, Lazarovits AI, Tidswell M 1994. Expression and function of the MAdCAM-1 receptor, integrin alpha 4 beta 7, on human leukocytes. J Immunol 153: 517.

Fryer AD, Costello RW, Yost BL, Lobb RR, Tedder TF, Steeber DA, Bochner BS 1997. Antibody to VLA-4, but not to L-selectin, protects neuronal M2 muscarinic receptors in antigen-challenged guinea pig airways. J Clin Invest (in press)

Fukuda T, Fukushima Y, Numao T, Ando N, Arima M, Nakajima H, Sagara H, Adachi T, Motojima S, Makino S 1996. Role of interleukin-4 and vascular cell adhesion molecule-1 in selective eosinophil migration into the airways in allergic asthma. Am J Respir Cell Mol Biol 14: 84.

Georas SN, Liu MC, Newman W, Beall WD, Stealey BA, Bochner BS 1992. Altered adhesion molecule expression and endothelial activation accompany the recruitment of human granulocytes to the lung following segmental antigen challenge. Am J Respir Cell Mol Biol 7: 261.

Georas SN, McIntyre BW, Ebisawa M, Bednarczyk J, Schleimer RP, Bochner BS 1993. Expression of a functional laminin receptor ( $\alpha 6 \beta 1$, VLA- 6 ) on human eosinophils. Blood 82: 2872.

Ginsberg MH, Du X, Plow EF 1992. Inside-out integrin signaling. Curr Opin Cell Biol 4: 766.

Gonzalo JA, Lloyd CM, Kremer L, Finger E, Martinez C, Siegelman MH, Cybulsky M, Gutierrezramos JC 1996. Eosinophil recruitment to the lung in a murine model of allergic inflammation - the role of t cells, chemokines, and adhesion receptors. J Clin Invest 98: 2332.

Gosset P, Tillie-Leblond I, Janin A, Marquette CH, Copin MC, Wallaert B, Tonnel AB 1994. Increased expression of ELAM-1, ICAM-1, and VCAM-1 on bronchial biopsies from allergic asthmatic patients. Ann NY Acad Sci 725: 163.

Grayson MH, Van der Vieren M, Gallatin WM, Hoffman PA, Bochner BS 1997. Expression of a novel B2 integrin $(\alpha \mathrm{d} \beta 2)$ on human leukocytes and mast cells. J Allergy Clin Immunol 99: S386.

Hamilos DL, Leung DYM, Wood R, Bean DK, Song YL, Schotman E, Hamid Q 1996. Eosinophil infiltration in nonallergic chronic hyperplastic sinusitis with nasal polyposis is associated with endothelial VCAM-1 upregulation and expression of TNF- $\alpha$. Am J Respir Cell Mol Biol 15: 443.

Hannigan GE, Leunghagesteijn C, Fitzgibbon L, Coppolino MG, Radeva G, Filmus J, Bell JC, Dedhar S 1996. Regulation of cell adhesion and anchoragedependent growth by a new beta-1-integrin-linked protein kinase. Nature 379: 91.

Hansel TT, Walker C 1992. The migration of eosinophils into the sputum of asthmatics: the role of adhesion molecules. Clin Exp Allergy 22: 345.

Hemler ME, Weitzman JB, Pasqualini R, Kawaguchi S, Kassner PD, Berdichevsky FB 1994. Structure, biochemical properties, and biological functions of integrin cytoplasmic domains, p. 1. In Y Takada, Integrin: the biological problem, CRC Press, Ann Arbor.

Hunt III SW, Kellermann S-A, Shimizu Y 1997. Integrins, integrin regulators and the extracellular matrix: the role of signal transduction and leukocyte migration, p. 73. In BS Bochner, Cell adhesion molecules in allergic disease, Marcel Dekker, New York.

Iademarco MF, Barks JL, Dean DC 1995. Regulation of vascular cell adhesion molecule-1 expression by IL4 and TNF-alpha in cultured endothelial cells. J Clin Invest 95: 264.

Jahnsen FL, Haraldsen G, Aanesen JP, Haye R, Brandtzaeg P 1995. Eosinophil infiltration is related to increased expression of vascular cell adhesion molecule-1 in nasal polyps. Am J Respir Cell Mol Biol 12: 624

Kaiser J, Bickel C, Bochner BS, Schleimer RP 1993. The effects of the potent glucocorticoid budesonide on adhesion of eosinophils to human vascular endothelium and on endothelial expression of adhesion molecules. J Pharmacol Exp Therap 267: 245.

Kassner PD, Alon R, Springer TA, Hemler ME 1995. Specialized functional properties of the integrin alpha(4) cytoplasmic domain. Mol Biol Cell 6: 661.

Kita H, Horie S, Gleich GJ 1996. Extracellular matrix proteins attenuate activation and degranulation of stimulated eosinophils. J Immunol 156: 1174.

Kroegel C, Liu MC, Hubbard WM, Lichtenstein LM, Bochner BS 1994. Blood and bronchoalveolar eosinophils in allergic subjects following segmental antigen challenge: surface phenotype, density heterogeneity, and prostanoid production. J Allergy Clin Immunol 93: 725. 
Kuijpers TW, Mul EPJ, Blom M, Kovach NL, Gaeta FCA, Tollefson V, Elices MJ, Harlan JM 1993. Freezing adhesion molecules in a state of high-avidity binding blocks eosinophil migration. J Exp Med 178: 279.

Kyan-Aung U, Haskard DO, Poston RN, Thornhill MH, Lee TH 1991. Endothelial leukocyte adhesion molecule- 1 and intercellular adhesion molecule- 1 mediate the adhesion of eosinophils to endothelial cells in vitro and are expressed by endothelium in allergic cutaneous inflammation in vivo. J Immunol 146: 521.

Lee B-J, Naclerio RM, Bochner BS, Taylor RM, Lim MC, Baroody FM 1994. Nasal challenge with allergen upregulates the local expression of vascular endothelial adhesion molecules. JAllergy Clin Immunol 94: 1006.

Lobb RR 1997. Adhesion molecule antagonists in animal models of asthma, p. 396. In BS Bochner, Adhesion molecules in allergic diseases, Marcel Dekker, Inc., New York.

Mannion BA, Berditchevski F, Kraeft S-K, Chen LB, Hemler ME 1996. Transmembrane-4 superfamily proteins CD81 (TAPA-1), CD82, CD63, and CD53 specifically associate with integrin $\alpha 4 \beta 1$ (CD49d/ CD29). J Immunol 157: 2039.

Matsumoto K, Sterbinsky SA, Bickel CA, Zhou DW, Kovach NL, Bochner BS 1997. Regulation of $\alpha 4$ integrin-mediated adhesion of human eosinophils to fibronectin and vascular cell adhesion molecule-1 (VCAM-1). J Allergy Clin Immunol (in press).

McArthur Lewis J, Schwartz M 1995. Mapping in vivo associations of cytoplasmic proteins with integrin $\beta 1$ cytoplasmic domain mutants. Mol Biol Cell 6: 151.

Miyamoto S, Teramoto H, Coso OA, Gutkind JS, Burbelo PD, Akiyama SK, Yamada KM 1995. Integrin function: molecular hierarchies of cytoskeletal and signaling molecules. J Cell Biol 131: 791.

Nagata M, Sedgwick JB, Bates ME, Kita H, Busse WW 1995. Eosinophil adhesion to vascular cell adhesion molecule- 1 activates superoxide anion generation. $J$ Immunol 155: 2194.

Neeley SP, Hamann KJ, Dowling TL, McAllister KT, White SR, Leff AR 1994. Augmentation of stimulated eosinophil degranulation by VLA-4 (CD49d)mediated adhesion to fibronectin. Am J Respir Cell Mol Biol 11: 206.

Ohkawara Y, Yamauchi K, Maruyama N, Hoshi H, Ohno I, Honma M, Tanno Y, Tamura G, Shirato K, Ohtani H 1995. In situ expression of the cell adhesion molecules in bronchial tissues from asthmatics with air flow limitation: in vivo evidence of VCAM-1/VLA4 interaction in selective eosinophil infiltration. $\mathrm{Am}$ J Respir Cell Mol Biol 12: 4.

Polito AJ, Proud D 1997. Epithelial cells: phenotype, substratum and mediator production, p. 43. In BS Bochner, Cell adhesion molecules in allergic disease, Marcel Dekker, New York.

Rankin JA, Picarella DE, Geba GP, Temann UA, Prasad B, Dicosmo B, Tarallo A, Stripp B, Whitsett J, Flavell RA 1996. Phenotypic and physiologic characterization of transgenic mice expressing interleukin 4 in the lung: lymphocytic and eosinophilic inflamma- tion without airway hyperreactivity. Proc Natl Acad Sci USA 93: 7821.

Resnick MB, Weller PF 1993. Mechanisms of eosinophil recruitment. Am J Respir Cell Mol Biol 8: 349.

Richards IM, Kolbasa KP, Hatfield CA, Winterrowd GE, Vonderfecht SL, Fidler SF, Griffin RL, Brashler JR, Krzesicki RF, Sly LM, Ready KA, Staite ND, Chin JE 1996. Role of very late activation antigen-4 in the antigen-induced accumulation of eosinophils and lymphocytes in the lungs and airway lumen of sensitized brown norway rats. Am J Respir Cell Mol Biol 15: 172.

Saini SS, Matsumoto K, Bochner BS 1997. Phenotypic and functional characteristics of adhesion molecules on human basophils, p. 129. In BS Bochner, Adhesion molecules in allergic diseases, Marcel Dekker, Inc., New York.

Schall TJ, Bacon KB 1994. Chemokines, leukocyte trafficking, and inflammation. Curr Opin Immunol 6: 865.

Schaller M, Parsons J 1994. Focal adhesion kinase and associated proteins. Curr Opinion Cell Biol 6: 705.

Schleimer RP, Sterbinsky SA, Kaiser J, Bickel CA, Klunk DA, Tomioka K, Newman W, Luscinskas FW, Gimbrone MA Jr, McIntyre BW, Bochner BS 1992. Interleukin-4 induces adherence of human eosinophils and basophils but not neutrophils to endothelium: association with expression of VCAM-1. J Immunol 148: 1086.

Seminario M-C, Sterbinsky SA, Bochner BS 1997. $\beta 1$ integrin-dependent adhesion in Jurkat cells is modulated by a serine-threonine phosphatase inhibitor. $J$ Allergy Clin Immunol 99: S174.

Shattil S, Ginsberg M, JS B 1994. Adhesive signaling in platelets. Curr Opinion Cell Biol 6: 695.

Shimizu Y, Van Seventer G, Horgan K, Shaw S 1990. Regulated expression and binding of three VLA $(\beta 1)$ integrin receptors on T cells. Nature 345: 250.

Shimizu Y, Van Seventer GA, Ennis E, Newman W, Horgan KJ, Shaw S 1992. Crosslinking of the T-cellspecific accessory molecules CD7 and CD28 modulates T-cell adhesion. J Exp Med 175: 577.

Springer TA 1990. Adhesion receptors of the immune system. Nature 346: 425.

Springer TA 1995. Traffic signals on endothelium for lymphocyte recirculation and leukocyte emigration. Annu Rev Physiol 57: 827.

Stark J, Godding V, Sedgwick JB, Busse WW 1996. Respiratory syncytial virus infection enhances neutrophil and eosinophil adhesion to cultured respiratory epithelial cells - roles of CD18 and intercellular adhesion molecule-1. J Immunol 156: 4774.

Teran LM, Davies DE 1996. The chemokines: their potential role in allergic inflammation. Clin Exp Allergy 26: 1005.

Tourkin A, Anderson T, LeRoy EC, Hoffman S 1993. Eosinophil adhesion and maturation is modulated by laminin. Cell Adhesion Commun 1: 161.

Wahl SM, Feldman GM, McCarthy JB 1996. Regulation of leukocyte adhesion and signaling in inflammation and disease. J Leukoc Biol 59: 789.

Walsh GM, Hartnell A, Wardlaw AJ, Kurihara K, 
Sanderson CJ, Kay AB 1990. IL-5 enhances the in vitro adhesion of human eosinophils, but not neutrophils, in a leucocyte integrin (CD11/18)-dependent manner. Immunology 71: 258.

Walsh GM, Mermod J, Hartnell A, Kay AB, Wardlaw AJ 1991. Human eosinophil, but not neutrophil, adherence to IL-1-stimulated human umbilical vascular endothelial cells is $\alpha 4 \beta 1$ (very late antigen-4) dependent. J Immunol 146: 3419.

Walsh GM, Symon FA, Lazarovits AI, Wardlaw AJ 1996. Integrin $\alpha 4 \beta 7$ mediates human eosinophil interaction with MAdCAM-1, VCAM-1 and fibronectin. Immunology 89: 112.

Walsh GM, Symon FA, Wardlaw AJ 1995. Human eosinophils preferentially survive on tissue fibronectin compared with plasma fibronectin. Clin Exp Allergy 25: 1128 .

Walsh GM, Wardlaw AJ 1997. Eosinophil interactions with extracellular matrix proteins: effects on eosino- phil function and cytokine production, p. 187. In BS Bochner, Adhesion molecules in allergic diseases, Marcel Dekker, Inc., New York.

Weber C, Alon R, Moser B, Springer TA 1996a. Sequential regulation of $\alpha 4 \beta 1$ and $\alpha 5 \beta 1$ integrin avidity by $\mathrm{CC}$ chemokines in monocytes: implications for transendothelial chemotaxis. J Cell Biol 134: 1063.

Weber C, Kitayama J, Springer TA 1996b. Differential regulation of $\beta 1$ and $\beta 2$ integrin avidity by chemoattractants in eosinophils. Proc Natl Acad Sci USA 93: 10939.

Werfel S, Yednock T, Matsumoto K, Sterbinsky S, Schleimer R, Bochner B 1996. Functional regulation of $\beta 1$ integrins and human eosinophils by divalent cations and cytokines. Am J Respir Cell Mol Biol 14: 45.

Yamada KM, Miyamoto S 1995. Integrin transmembrane signaling and cytoskeletal control. Curr Opin Cell Biol 7: 681. 